\title{
THE ROLE OF TRAINING IN SHAPING PRE-SERVICE TEACHER COGNITION RELATED TO L2 PRONUNCIATION
}

\begin{abstract}
This study analyzed changes in the pronunciation-related cognitions of undergraduate TESL students from two Canadian universities during their first term in their programs. The students from one university attended a 13week course in phonology and pronunciation teaching, while those from the other university received no specific training in pronunciation. Towards the end of the term, the participants who received specialized training had more favorable views of explicit pronunciation teaching and became more confident in their ability to teach pronunciation than the comparison group. The course also helped the participants increase in awareness of their own speech and limitations. The findings point to the importance of native-nonnative speaker interactions in shaping cognitions and suggest that more support to nonnative-speaking TESL students and more training in the use of communicative activities would be helpful.
\end{abstract}

Keywords: pronunciation; Teacher cognition; TESL

\section{Introduction}

Several researchers have identified a need among English as a Second Language (ESL) teachers for more specialized training in pronunciation pedagogy (e.g., Derwing \& Munro, 2005; Foote, Holtby, \& Derwing, 2011). However, the effects of this type of training on pre-service and in-service teachers' beliefs and practices have not been sufficiently explored. Thus, we still lack knowledge or insight into what constitutes effective teacher training in second language (L2) pronunciation. The present study addressed this gap in the literature by investigating changes in the cognitions of pre-service ESL teachers after taking an undergraduate course in phonology and pronunciation teaching. Teacher cognition (TC) is here defined as the "cognitive dimension of teaching - what teachers know, believe, and think" (Borg, 2003, p. 81). This study focuses specifically on teachers' beliefs, as there is compelling evidence to suggest that what teachers believe can affect their behavior in class and learner outcomes. Self-efficacy, for example, which is defined as teachers' belief in their ability to influence students' performance (Bandura, 1977; Tschannen-Moran, Hoy, \& Hoy, 1998), has been found to positively correlate with willingness to try out different practices (Ghaith \& Yaghi, 1997; Smylie, 1988) and with learning outcomes (Ashton \& Webb, 1986).

\section{L2 Teacher Cognition}

According to Borg (2006), many factors can influence TC, including personal experiences, professional coursework, and classroom practice. The

\footnotetext{
${ }^{*} \mathrm{PhD}$ candidate in Education specializing in Applied Linguistics at Concordia University, in Montreal. She holds a Bachelor's degree in Teaching of English as a Foreign Language and Portuguese and a master's degree in Applied Linguistics from her home country Brazil. Her research interests include teacher education, pronunciation instruction, and second language phonetics and phonology. Her e-mail address is larissacks@gmail.com.
} 
importance of these aspects has been underscored by several TC studies involving pre-service and in-service L2 teachers. Teachers having learned the language as nonnative speakers (NNSs), for example, is one factor that has been found to potentially influence their TC. The vast majority of nonnative-speaking teachers surveyed by Reves and Medgyes (1994) reported that they had language difficulties, especially with vocabulary and speaking, and that they believed these difficulties affected their teaching to some extent. Similar results were found by Samimy and Brutt-Griffler (1999), who analyzed classroom discussions, interviews, and autobiographical accounts by 17 students (all NNSs) enrolled in a graduate-level Teaching English to Speakers of Other Languages (TESOL) seminar in the United States. The participants reported having language difficulties in several areas, and most of them believed that these difficulties hindered their teaching.

Another factor that can influence TC is professional coursework. Mattheoudakis (2007) administered the Beliefs about Language Learning Inventory (BALLI) (Horwitz, 1985) questionnaire to a group of 36 preservice English as a Foreign Language (EFL) teachers at three time points over the course of a teacher education program in Greece. She observed several changes in the participants' responses, including weaker beliefs in the primacy of vocabulary and grammar teaching and in the importance of correct pronunciation, possibly resulting from the communicative training they received. Similarly, MacDonald, Badger, and White (2001) reported changes in the beliefs of 55 TESOL students in Scotland after a semester of courses in SLA. These changes were reflected in the participants' responses to a questionnaire on language learning based on Lightbown and Spada (1995, p. xv). After studying SLA, many of the participants' initial common-sense beliefs became more informed by research, while no significant changes were observed in the beliefs of a comparison group of 25 undergraduates in EFL and Initial Teacher Education programs that did not include instruction in SLA.

Finally, classroom practice can change TC (Borg, 2006). Evidence of this was found by Bateman (2008), who observed that 10 student teachers of Spanish as a second language experienced changes in their beliefs about target-language use in the classroom after a semester of practicum. As revealed by their responses to a pre/post questionnaire, the students lowered their expectations regarding the use of the target language to give instructions for assignments and projects and to provide cultural information. The above-mentioned study by Mattheoudakis (2007) also analyzed the beliefs of a second group of 30 student teachers from the same program in Greece who had chosen to do a teaching practicum in their final year of studies. The beliefs of this group (called "practice group") were assessed only at the end of the program, i.e., Time 3. Compared to the first group of 36 student teachers (the "non-practice group"), they seemed to be more critical of their EFL teachers and the teaching they had received as language learners. At the same time, several of their beliefs were traditional and more in tune with their grammar-based learning experience than with the communicative training program they had completed. According to Mattheoudakis, the classroom reality might have caused them to re-evaluate the theoretical knowledge acquired during the program.

Clearly, TC is a complex phenomenon affected by several factors. Research on this topic can support preservice and in-service teacher education by investigating how training may shape TC, possibly helping to change misinformed, incomplete, or unconstructive cognitions. However, very little research in the field of L2 pronunciation has explored this issue.

\section{Teacher Cognition in L2 Pronunciation}

Almost all known studies on TC related to pronunciation have employed cross-sectional designs to explore the current beliefs and practices of inservice and often experienced ESL teachers who were not undergoing training. These studies have explored teachers' level of training in pronunciation pedagogy, activities and techniques used to teach pronunciation, and the most frequently taught pronunciation features, as well as teachers' beliefs about pronunciation teaching and learning and about their own ability to teach pronunciation. Research in ESL contexts includes surveys of teachers and program coordinators 
conducted in the UK by Burgess and Spencer (2000), in Australia by Burns (2006), and in Canada by Breitkreutz, Derwing, and Rossiter (2001) and Foote, Holtby, and Derwing (2011), as well as interview studies conducted by Macdonald (2002) in Australia and by Baker (2011b) in the United States. More survey and interview research has been done with teachers from EFL settings, including Greece (Sifakis \& Sougari, 2005), Northern Cyprus (Hismanoglu \& Hismanoglu, 2010), Finland (Tergujeff, 2012a, 2012b), Brazil (Albini \& Kluge, 2011; Buss, 2016), Uruguay (Couper, 2016), and several others (Henderson, 2013; Jenkins, 2005; Timmis, 2002). A common finding in many of these studies is that ESL/EFL teachers lack confidence in teaching pronunciation and would like more training in the field.

Buss (2013) adopted a different method from the above studies in that it sought to understand the pronunciation-related cognitions of pre-service EFL teachers in Brazil by means of an analysis of their teaching practicum reports. However, given that the reports did not deal exclusively with pronunciation, a relatively small amount of data was obtained. More importantly, the student teachers had received training in phonology and pronunciation pedagogy years before their practicum, and there was no pre-measure of their cognitions or control group for comparison. Therefore, potential links between training and TC related to pronunciation were not clear-cut.

\section{Teacher Training and Teacher Cognition in L2 Pronunciation}

To date, few studies in L2 pronunciation have researched the influence of training on TC. This is an important topic of investigation because specialized training in the field has often been called for as an answer to teachers' self-reported lack of knowledge or confidence to teach pronunciation (Couper, 2016; Foote et al., 2011; Macdonald, 2002). Nonetheless, how and to what extent training can actually promote positive changes to these teachers' cognitions about pronunciation is not fully understood. Baker (2011a, 2014) indirectly addressed this issue in her investigation of the cognitions and classroom practices of five experienced ESL teachers. The earlier study (2011a) sought to determine the source of these teachers' knowledge of pronunciation pedagogy. When asked during interviews, three of the five teachers identified an MA-level course in pronunciation pedagogy as having the greatest impact on their teaching of pronunciation. Classroom observations confirmed this finding, as many of the techniques and activities that they reported learning in the graduate course were used in their classes. The other two teachers, who had not taken a graduate course specifically devoted to pronunciation pedagogy, identified other factors as playing a prominent role. The only one of the five who had little or no training in pronunciation pedagogy also mentioned that she felt insecure teaching pronunciation. In Baker (2014), the same three teachers who had completed a graduatelevel course in pronunciation pedagogy were found to use a larger range of pronunciation teaching techniques than the other two. Still, most of the techniques used were controlled ones, which are less communicative and more carefully constrained by the instructor. Although interesting, Baker's conclusions were drawn long after training, so the development of TC throughout the course, as well as more specific links between the kind of training received and cognition changes, could not be fully explored.

Burri (2015a, 2015b) and Burri, Baker, and Chen (2017) used a longitudinal case study design in order to look more directly at the role played by teacher education in shaping TC. They explored the cognition development of 15 ESL student teachers, including native speakers (NSs) and NNSs of English, during a 13-week graduate course in pronunciation pedagogy. Data were collected from interviews, focus groups, questionnaires, and classroom observations. Some changes were observed in the cognitions of the participants, especially a heightened awareness of the importance of suprasegmentals and of NNSs' ability to teach pronunciation (Burri, 2015b). It was found that the cognition development of NNSs was stimulated by an increased awareness of their English speech and the perception that their own pronunciation improved with the course. NSs, on the other hand, benefited more from their interactions with NNS classmates, which helped 
them realize that NNSs could be effective pronunciation teachers. In Burri (2015a), the same participants were reported to have become more aware of nonnative English varieties and accents, which in turn led them to believe that the goal of pronunciation teaching should not be accent elimination. A later analysis by Burri et al. (2017) indicated that the participants became more aware of the benefits of kinesthetic/tactile teaching techniques. However, they still favored controlled activities - the kind they had experienced as L2 learners - when writing an end-of-course assignment in which they provided recommendations on how to address certain pronunciation problems.

Burri's research is the first to investigate the longitudinal development of pronunciation TC in a teacher education program. However, several of its participants had years of teaching experience and some had previous training in TESL or related areas. It is necessary to determine whether similar outcomes would be observed for student teachers in undergraduate programs who have little or no teaching experience. Considering many ESL teachers working in schools do not hold a graduate degree, it is important to know whether pronunciation training at the undergraduate level, given to less experienced or less educated student teachers, can also inspire positive changes in TC. Furthermore, a weakness of Burri's study is that it does not attempt to sort out the influence of specific pronunciation training from that of other TESL courses on student teachers' cognitions. In other words, the pronunciation-related cognition development observed by Burri may have also been influenced by other courses in the TESL program, and not only by the specific course in pronunciation pedagogy. Thus, it is helpful to have a control group of TESL students who are not undergoing pronunciation training, so as to compare their cognitions over time to those of the treatment participants.

\section{The Current Study}

In this longitudinal study, the gaps identified in the literature review were addressed by exploring the developing cognitions of pre-service ESL teachers in an undergraduate university course in phonology and pronunciation teaching. The course consisted of a taught portion on phonology and pronunciation teaching and a short teaching practicum at the end, in which student teachers prepared and taught pronunciation tutorials to ESL learners. The participants' cognition changes were compared to those of a control group of undergraduate pre-service TESL teachers who had received no specific training in phonology or pronunciation pedagogy.

The main research questions addressed by the study were the following:

1. How do TESL student teachers' cognitions about pronunciation change after the taught portion of an undergraduate course in phonology and pronunciation teaching, and how are the identified changes related to the course content and activities?

2. How do these changes compare to those experienced by TESL student teachers who do not receive any specific training in phonology and pronunciation teaching?

3. What further cognition changes (if any) take place after the pronunciation teaching practicum, and how are these changes linked to the course or to the practicum?

\section{Method}

\section{Participants}

The treatment group participants in the study were first-year undergraduate TESL students at a Canadian university who were enrolled in a phonology and pronunciation teaching course offered in the fall term. The same instructor taught two groups: one had classes in the afternoon twice a week ( $1 \mathrm{~h} 15$ each) and the other had classes in the evening once a week (2h15). Both groups included students in a four-year Bachelor of Education program and students in a one-year TESL certificate program. Comparable TESL students from another university who received no instruction on phonology and pronunciation teaching in their first 
year were recruited to participate as a comparison group. Both NSs and NNSs of English were included in the sample.

In total, there were 18 students in the treatment group and 15 students in the comparison group. Most of the treatment participants (13) were from the afternoon group, with only five being from the evening group. Part of the comparison data was collected in the fall of one year (six participants). The rest were collected the following fall (nine participants), along with the treatment group data. The 15 comparison participants were all from the same university. No changes were made to the curriculum of the program from the first to the second year of data collection. Table 1 shows the TESL courses that were taken by the participants. All of the participants took a grammar course and almost all of them received some instruction in general L2 teaching, but only the treatment group took a course in English phonology and pronunciation teaching.
Of all participants $(n=33)$, most were females ( $n=$ $29)$ in their 20s $(n=19)$ from the Greater Montreal area $(n=18)$. The majority considered themselves to be native speakers of English $(n=25)$, although some reported having more than one native language, with English and French being the most common combination $(n=9)$. With few exceptions, the participants had no prior training in TESL or pronunciation pedagogy and little or no experience teaching ESL at the start of the study (see Table 2). The treatment group differed from the comparison group in that the treatment group had males and a few mature students. Four of the treatment participants were in their 30s and three were over 50 years old. There were also two participants who had extensive TESL experience in their non-Englishspeaking home countries: one had taught for seven and a half years and the other for more than 10 years.

Table 1

Treatment and Comparison Groups TESL Courses

\begin{tabular}{|c|c|c|c|}
\hline & Treatment Group & & Comparison Group \\
\hline Courses & BEd & Certificate & BEd \\
\hline $\begin{array}{l}\text { English phonology and/ } \\
\text { or pronunciation }\end{array}$ & $\checkmark(3$ credits $)$ & $\checkmark(3$ credits $)$ & $x$ \\
\hline English grammar & $\checkmark(3$ credits $)$ & $\checkmark(3$ credits $)$ & $\checkmark$ (3 credits) \\
\hline General L2 teaching & $\begin{array}{l}\checkmark \text { TESL pedagogy (6 } \\
\text { credits): observation } \\
\text { and assistance in ESL } \\
\text { classes, examination of } \\
\text { L2 teaching approaches } \\
\text { and methodologies, and } \\
\text { discussion of relevant } \\
\text { issues to the ESL } \\
\text { classroom }\end{array}$ & $\begin{array}{l}\checkmark \text { TESL methodology ( } 3 \\
\text { credits): review of theory } \\
\text { in applied linguistics } \\
\text { directly related to L2 } \\
\text { teaching and discussion } \\
\text { of teaching methods and } \\
\text { techniques }\end{array}$ & $\begin{array}{l}\checkmark \text { L2 education ( } 3 \text { credits): focus } \\
\text { on L2 teaching methods and } \\
\text { approaches from a historical and } \\
\text { analytical perspective } \\
\checkmark \text { Classroom observation ( } 2 \\
\text { credits): "participant observer" } \\
\text { field experience at a school }\end{array}$ \\
\hline & & & $\begin{array}{l}\checkmark \text { Professional seminar ( } 1 \\
\text { credit): how to observe L2 } \\
\text { classrooms and reflection on } \\
\text { the classroom observation } \\
\text { experience }\end{array}$ \\
\hline
\end{tabular}

${ }^{*}$ This course was not required in the first term, so it was not taken by all participants from the BEd program. 
Table 2

Participant Demographics

\begin{tabular}{lll}
\hline & Treatment & Comparison \\
\hline $\mathbf{N}$ & 18 & 15
\end{tabular}

Sex

Male

Female

Age (yrs)

Median

Range

Birthplace

Greater Montreal

Other Quebec

Other Canada

Abroad

Native language(s)

English only

English and other(s)

Other(s)

$4 \quad 0$

24.5

18-63

20

$14 \quad 15$

10

(0)

15

$$
\text { 18-23 }
$$

8

1

0

6

(20

$\begin{array}{ll}7 & 4 \\ 6 & 8 \\ 5 & 3\end{array}$

TESL or pronunciation pedagogy training*

$\begin{array}{lll}\text { No } & 15 & 13\end{array}$

$\begin{array}{lll}\text { Yes } & 2 & 0\end{array}$

ESL teaching experience

$\begin{array}{lll}\text { None } & 11 & 13\end{array}$

Less than 6 months $\quad 5 \quad 0$

1 year or more $\quad 0 \quad 2$

7 years or more $\quad 2 \quad 0$

L2 pronunciation teaching experience

$\begin{array}{lll}\text { No } & 16 & 14\end{array}$

Yes 21

$\overline{ }{ }^{\bar{N}}$ No answer given by three participants.

The subset of treatment participants who were interviewed represented different age groups and birthplaces and included both NSs and NNSs of English (see Table 3). It was representative of the sample in that it had mostly female participants with little or no experience teaching ESL.

Table 3

Interviewed Treatment Participants

\begin{tabular}{llllll}
\hline Name $^{*}$ & Age & Gender & Birthplace & $\begin{array}{l}\text { Declared English-speaking } \\
\text { status }\end{array}$ & $\begin{array}{l}\text { ESL teaching } \\
\text { experience }\end{array}$ \\
\hline Margaret & 63 & F & USA & Native & None \\
Amanda & 29 & F & Peru & Nonnative & None \\
Kassim & 21 & M & Canada (Montreal) & Native & None \\
Christine & 21 & F & Canada (Quebec) & Nonnative & None \\
Parvin & 33 & F & Iran & Nonnative & $10+$ years \\
Jennifer & 24 & F & Canada (Montreal) & Native & None \\
Leslie & 25 & F & Canada (Montreal) & Native & None \\
Lynn & 52 & F & Netherlands & Native & 3 months \\
\hline
\end{tabular}

"Names have been changed to preserve confidentiality.

\section{Data Collection}

Phase 1: Questionnaires. There were two phases to the study. The first phase used a web-based questionnaire hosted on Survey Monkey to explore students' cognitions before and after the theoretical portion of the TESL course in phonology and pronunciation teaching. Both treatment and comparison groups 
participated in the first phase. Recruitment for the pre-treatment questionnaire took place in the second week of class (mid-September - Time 1), per the two TESL instructors' requests, and the participants were given approximately two weeks to complete the questionnaire. The post-questionnaire was completed in mid-November (Time 2), before the treatment group taught their first pronunciation tutorial.

The questionnaires were fairly long (76 items) and covered several topics, most of which were related to the participants' background, beliefs about pronunciation teaching and learning, and beliefs about their selfefficacy as pronunciation teachers. The majority of the questionnaire items were worded as statements with which the participants indicated their level of agreement on a 7-point scale (from " 0 " = strongly disagree to " 6 " $=$ strongly agree). Some of the items were written by the researcher drawing on topics from the literature on pronunciation and TC; others were taken from the instrument developed by Foote et al. (2011), and yet others were adapted from the Self-efficacy Teaching and Knowledge Instrument for Science Teachers (SETAKIST), designed by Roberts and Henson (2000). The complete questionnaire given to NSs from the treatment group at Time 1 can be found in Appendix A. The main difference between the questionnaire version given to NSs and the one given to NNSs was that the latter featured questions about their experiences learning ESL rather than other second languages. The version given to the comparison group was slightly different in that it did not refer specifically to the pronunciation tutorials taught as part of the pronunciation course, but to teaching pronunciation in general in the future. The only difference between Time 1 and Time 2 questionnaires was that the latter did not repeat certain questions background (e.g., gender, date of birth, native language, etc. $)^{1}$.

The internal consistency of the questionnaire items designed to assess the construct of self-efficacy was good, with a Cronbach's alpha of .82 at pretest and .90 at posttest. The other constructs addressed in the questionnaire were not considered for reliability analyses because they were measured by too few items (usually just one or two) or by open-ended questions. The questionnaire response rates were approximately
$26 \%$ for the pool of treatment group students and 20\% for the pool of comparison group students. During Phase 1, the researcher also contacted the instructor responsible for the TESL course in phonology and pronunciation teaching and was given access to the Moodle sites for the course. Each of the two groups taught by the instructor (afternoon and evening) had their own Moodle site, which contained the materials used in class, as well as the course outline, homework, and assignment guidelines. The researcher was able to download all of these documents for analysis.

Phase 2: Interviews. The second phase of the study took place after the treatment participants finished their teaching practicum in early December and involved a smaller sample of eight participants from the treatment group. They volunteered to participate in the interviews following an email invitation sent by the researcher to the whole group. As a final project for their TESL course, the students in the treatment group were required to put together a pronunciation teaching portfolio, which included their individual lesson plans for the teaching practicum, descriptions of procedures, materials used, and reflections on the experience. Those who agreed to participate in the second phase of the study gave the researcher access to their portfolios and were interviewed individually, in English, a few days later. This interview was semi-structured and probed more deeply into cognition changes observed in the pre/post questionnaires and any further changes resulting from the practicum experience. The researcher asked general questions about what the participants thought of the teaching experience and whether they thought something had changed in their knowledge and beliefs related to pronunciation after it. All of them were asked whether they felt more or less confident in teaching pronunciation in the future. Specific questions were created based on the participants' answers to the questionnaires and on what they had written in their pronunciation teaching portfolios.

\section{Analysis}

Materials. The analysis of the TESL course materials was based on the contents of the Moodle sites. 
These sites were well organized and constantly updated by the professor with PowerPoint slides and handouts used in class, activities and/or answer keys to activities done in class, extra resources, homework for upcoming classes, as well as the course outline and guidelines for assignments. The first step in the analysis was to read the course outlines and the dashboard pages of the Moodle sites in order to have an overview of the course, especially the topics covered, their distribution over the 13 weeks, and the types of activities used. The second step was to classify the resources according to the topics they addressed and their types - "PowerPoint files", "handouts", "activities", or "homework" - and count them. Then, the researcher looked for potential differences between the teaching received by the afternoon group and the evening group by comparing the dashboard pages of the two Moodle sites. An overall percentage of difference between the two sites was calculated.

Questionnaires. The analysis of the questionnaires focused on the findings related to the main topics of interest in this study: the participants' beliefs about pronunciation teaching and learning (addressed in Section II, no. 2, of the questionnaire in Appendix A) and beliefs about their self-efficacy as pronunciation teachers (addressed in Section III except letters "b", "e", and "f"). The first step in the analysis was to develop a demographic profile of the participants. Then, percentage tables were created to summarize the participants' responses to the 22 questionnaire items that addressed cognitions about pronunciation teaching and learning. For ease of comparison, the 7-point responses were reduced to three: "disagree" (including responses 1-3: "strongly disagree", "disagree", and "tend to disagree"), "unsure or neutral" (response 4 ), and "agree" (including responses 5-6: "tend to agree", "agree", and "strongly agree"). For some of the statements, higher agreement (i.e., a higher response number) indicated higher self-efficacy, such as "I know what to do to teach pronunciation effectively". For others, such as "I feel anxious about having to teach English pronunciation", higher agreement suggested lower self-efficacy. Thus, some responses needed to be recoded so that higher numbers always reflected higher self-efficacy. Self-efficacy means were then calculated for each participant at Time 1 and Time 2 by averaging their responses to the 19 questionnaire items that addressed this construct. Finally, statistical analyses were conducted in order to compare the two groups and test for any significant changes from Time 1 and Time 2.

Interviews. The interviews were first transcribed and read by the researcher. Relevant data were organized using three a priori categories based on the research questions (Miles, Huberman, \& Saldaña, 2014): “TESL course influence on cognitions", "Practicum influence on cognitions" and "Other", which was reserved for any additional information on the participants' cognitions which did not fit into the first two categories. The organized data were read again and coded for recurring topics or ideas which indicated cognition changes and experiences that were common across participants.

\section{Pronunciation Teaching Course}

During the course of the study, the treatment group received specialized training in the form of a 13-week undergraduate TESL course in phonology and pronunciation teaching. The course was taught by a $\mathrm{PhD}$ in applied linguistics who was a researcher in $\mathrm{L} 2$ pronunciation and had more than 10 years of experience teaching higher education. Because the instructor posted all of the course materials on Moodle, it was possible to have a fairly good overview of each class and the course as a whole. This section will provide a description of the TESL course, based on the analysis of the course materials. This description is needed in order to understand how the course and practicum may have influenced TC.

\section{Goal and Contents}

According to the outline, the course had four instructional goals:

- to provide students with an overview of the sound system of English organized around three main topics-sound-, word-, and phrase-level phonology; 
- to demonstrate to students how theoretical information about the sound system of English can be applied to classroom teaching of pronunciation;

- to help students create materials for teaching pronunciation to learners of English;

- to provide students with an opportunity to practice teaching pronunciation to learners of English.

The required text for the course was Lane's (2010) Tips for Teaching Pronunciation. A schedule of topics in the course outline indicated the pages or chapters of the book that the students were expected to read before each class. The first week of class was an introduction to the course and included a lecture on basic issues in the field and a group activity (see details in Table 4). After the first week, the course was organized into three fourweek blocks, covering segmentals, suprasegmentals, and pronunciation teaching. The first two blocks of the course were theoretical, and classes consisted mainly of lectures to introduce new topics followed by practice activities. Each of these blocks ended with an exam.

\section{Table 4}

Pronunciation Teaching Course Overview

\begin{tabular}{|c|c|c|}
\hline Week & Content & Details \\
\hline 1 & Introduction & $\begin{array}{l}\text { - Topics: Definition, scope, and importance of phonology; the role of age and L1 in } \\
\text { L2 pronunciation; the relationship between perception and production; the goals of } \\
\text { pronunciation teaching } \\
\text { - Group activity: students listened to recordings of L2 speakers, identified pronunciation } \\
\text { "problems", and gave examples of how they could help the speakers }\end{array}$ \\
\hline $2-5$ & $\begin{array}{l}\text { Individual } \\
\text { sounds }\end{array}$ & $\begin{array}{l}\text { - Consonants: how consonants are produced; the vocal tract; articulators; description of } \\
\text { consonants (place of articulation, manner of articulation, and voicing); phonetic symbols } \\
\text { - Vowels: description (height, backness, lip rounding, and tenseness); the schwa sound; } \\
\text { phonetic symbols } \\
\text { - Phonemes and allophones: definition and importance of contrastive sounds; minimal } \\
\text { pairs; examples of positional variation (aspiration, flapping, glottal stop, dark and light /l/, } \\
\text { /r/ coloring) } \\
\text { - Exam 1 }\end{array}$ \\
\hline $6-9$ & $\begin{array}{l}\text { Suprasegmental } \\
\text { features }\end{array}$ & $\begin{array}{l}\text { - Word stress: definition; levels (major, minor, and no stress); full vs. reduced vowels } \\
\text { - Rhythm: definition; properties (intensity, pitch height, and vowel duration); stress-timed } \\
\text { vs. syllable-timed; importance; characteristics (alternation of peaks and valleys and regular } \\
\text { timing); content vs. function words; natural speech phenomena } \\
\text { - Sentence stress: definition; characteristics; functions; importance; placement rules } \\
\text { - Exam } 2\end{array}$ \\
\hline $10-13$ & $\begin{array}{l}\text { Pronunciation } \\
\text { teaching }\end{array}$ & $\begin{array}{l}\text { - In class: how to administer a diagnostic test; pronunciation teaching; how to write } \\
\text { pronunciation activities; examples and analyses of pronunciation activities } \\
\text { - Outside class: prepare and teach four pronunciation tutorial classes to an L2 speaker } \\
\text { - Tutorial 1: diagnostic test } \\
\text { - Tutorials 2-4: total } 90 \text { minutes of pronunciation teaching } \\
\text { - Pronunciation teaching workshop: students gave a short in-class presentation about their } \\
\text { tutorial experience. Suggested topics: most or least successful activity, what they learned } \\
\text { about pronunciation teaching or English phonology, and their L2 learner's progress. } \\
\text { - Teaching portfolio submission: copies of lesson plans and teaching materials; brief } \\
\text { self-evaluations reflecting on their teaching; peer-evaluations reflecting on their partner's } \\
\text { teaching }\end{array}$ \\
\hline
\end{tabular}


The final block of the course started with a demonstration by the instructor of how to administer a pronunciation diagnostic test. The following classes included short lectures and examples of pronunciation activities. Some of the guidelines for writing pronunciation activities and many of the sample activities were bound together in a course pack. During this block, the students were also required to prepare and teach four pronunciation tutorial classes to an L2 speaker. The TESL students were paired up by the professor and each pair was assigned one L2 learner. On their first meeting with the learner, they administered a diagnostic test and each TESL student chose a small number of pronunciation features (usually one or two) to teach for approximately 30 minutes during each of the next three tutorials (for a total of 90 minutes of teaching time for each TESL student). Most of the preparation and all of the teaching took place outside of class time. This pronunciation teaching block ended with a pronunciation teaching workshop and with the submission of a teaching portfolio (see Table 4 for details).

\section{Materials}

The course materials were of four types: PowerPoint slides, handouts, activities and their answer keys, and homework. PowerPoint slides were used by the instructor to facilitate his lectures, which introduced new topics, usually at the beginning of the class. Handouts were either looked over in class or provided as extra resources for the students, including sound charts, diagrams, explanations, examples, sample activities or lesson plans, the course outline, and guidelines for evaluations. The activities were done in class and gave the students a chance to practice whatever was discussed in the slides. They included tasks such as identifying sounds, matching, transcribing, explaining, etc. The instructor would check the answers in class or post the answer key on Moodle. All activities but one involved only written words, sentences or texts, with no audio. There were, however, a few audio examples in the PowerPoint slides. Homework consisted of one to three exercises that were usually similar to the activities done in class. They gave the students extra practice on the topic discussed in the previous class and counted towards final grades.

The course materials were almost the same for the two TESL groups. The only differences were that the afternoon group did four additional activities in class (out of a total of 27 activities) and that each of the groups received two handouts that the other did not (out of a total of 41 handouts). Thus, out of a total of 84 resources posted on Moodle (not including answer keys of already posted activities), only eight differed between the groups, which is a $9.5 \%$ difference. Table 5 shows how many of the total number of resources (i.e., files) posted on Moodle address each course topic. Overall, the resources were evenly divided between the two theoretical blocks of the course (segments and suprasegmentals), except for the greater number of handouts on segments, which was due to the several sound charts and sets of phonetic symbols provided to the students. A large number of handouts were also given in the last block, pronunciation teaching, and consisted mostly of sample pronunciation activities. Compared to consonants and vowels, the students did not get as much practice on phonemes and allophones (only one activity in class), as shown in Table 5. Word stress was the most practiced suprasegmental feature (six activities and three pieces of homework). As for pronunciation teaching, although there were almost no in-class activities (only one of the two groups did an activity in which they analyzed and evaluated pronunciation activities), the students practiced choosing and writing pronunciation activities in preparation for their tutorials. They also had the opportunity to critique pronunciation activities (their own and their tutorial partner's) in their portfolios. 
Table 5

Course Resources by Topic

\begin{tabular}{lllll}
\hline & PPT files & Handouts & Activities & Homework \\
\hline Total & $\mathbf{1 0}$ & $\mathbf{4 1}$ & $\mathbf{2 7}$ & $\mathbf{6}$ \\
\hline Introduction and course guidelines & $\mathbf{1}$ & $\mathbf{1 0}$ & $\mathbf{1}$ & $\mathbf{0}$ \\
Segments & $\mathbf{4}$ & $\mathbf{9 - 1 0}$ & $\mathbf{1 1 - 1 3}$ & $\mathbf{3}$ \\
$\quad$ Consonants & 1 & 7 & $6-8$ & 2 \\
$\quad$ Vowels & 1 & $2-3$ & $9-10$ & 1 \\
$\quad$ Phonemes and allophones & 2 & 0 & 1 & 1 \\
Suprasegmentals & $\mathbf{3}$ & $\mathbf{2 - 3}$ & $\mathbf{1 0 - 1 1}$ & $\mathbf{3}$ \\
$\quad 1$ & 0 & 6 & 3 \\
$\quad$ Word stress & 1 & 1 & 2 & 0 \\
$\quad$ Rhythm & 1 & 1 & 2 & 0 \\
$\quad$ Natural speech phenomena & 1 & $0-1$ & $3-4$ & 1 \\
$\quad$ Sentence stress & 1 & $\mathbf{1 8}$ & $\mathbf{0 - 1}$ & $\mathbf{0}$ \\
\hline
\end{tabular}

Note. Main topics are shown in bold, with subtopics listed below. Some files addressed more than one subtopic (e.g., consonants and vowels), thus totals for the topics do not equal the sums of the subtopics. Ranges (e.g., 9-10 handouts on segments) mean that the number differed between the afternoon and the evening groups.

\section{Results}

\section{Cognition Changes After Theory}

This part of the results section will address changes in the participants' cognitions from the first questionnaire, which was given at the beginning of their first term in the TESL program, to the second questionnaire, given two months later. This coincides with the end of the theoretical blocks of the treatment group's phonology course, just before the start of the pronunciation teaching tutorials.

Changes in beliefs about pronunciation teaching and learning. Changes for each group over time and differences between groups on the questionnaire items that addressed cognitions about pronunciation teaching and learning were analyzed using Wilcoxon signed-rank tests and Mann-Whitney tests. Parametric statistics could not be used because the data violated the normality assumption. The complete results for all of the items can be found in Appendix B. Table 6 below displays only those items for which significant differences within and/or between groups were found. As can be seen from the running of Wilcoxon signedrank tests, a significant change over time was only found in the comparison group's response to item " $\mathrm{s}$ " $(Z=-2.233, p=0.026)$. That is, two months into their first term of studies, the comparison group agreed significantly less that ESL learners benefit from paying conscious attention to the input and becoming aware of how different features are produced. On the other hand, agreement with this statement increased for the treatment group; Mann-Whitney $\mathrm{U}$ tests showed that the two groups became significantly different from each other at Time $2(U=70.5, p=0.018)$.

Despite the fact that most of the response changes over time were not significant, some of them resulted in between-group differences at Time 2. As was the case for item "s", the differences found for items "a", " $m$ ", and "o" suggest that, compared to the comparison group, at Time 2 the treatment group held significantly more favorable views of explicit pronunciation teaching and learning. They believed significantly more than the comparison group that pronunciation teaching was not dispensable ( $U=61.5, p=0.011)$, that it was important to know phonology to teach pronunciation $(U=58, p=$ 
0.008 ), and that it was not boring to teach it ( $U=48, p$ $=0.001)$. Even at Time 1, the vast majority of treatment participants disagreed that teaching pronunciation was boring (94.4\%), as opposed to only $66.7 \%$ of the comparison group, which was also a significant difference ( $U=53.5, p=0.002)$. The two groups' responses to item " $k$ " were significantly different at Time $1(U=80, p=0.048)$, but not at Time 2 , when there was an increase in the percentage of comparison group participants who agreed that some individuals resist changing their pronunciation to maintain their identity (from $40 \%$ to 53\%). The treatment group's agreement with this statement was high at both time points (72.2\%).

The phonology course had an important role in shaping the treatment group's cognitions about pronunciation teaching and learning, as suggested by several comments made by the eight participants who were interviewed at the end of the term. The interviewees often made direct reference to the course and to the professor, Peter (not his real name), when explaining their views of a particular subject or when asked why certain answers had changed over time, as in the following examples:

"Um... but I think like Peter said at the end of the semester, he said, like, try to do just uh... little pronunciation things, like, try to just insert them in your lessons..." (Christine talking about teaching pronunciation in general ESL classes)

"Well, because I have learned a lot about how to teach the pronunciation, you know, developed a material, and uh... I thought that, well, OK, if a teacher can do that much, if a teacher can have all these resources and use them in a positive, useful way in a class, then teaching pronunciation is seriously important." (Parvin referring to questionnaire item "a" from Section II, no. 2)

"No, I mean, from a common-sense point of view I would have said no, it's not... I tend to think that it's not a good idea to teach to get rid of the accent completely. But now, from having done the course, of course it's not! (...) I know one thing Peter said, that sometimes a strong accent, even if you can understand, sometimes there's gonna be more prejudice." (Lynn referring to item "f" from Section II, no. 2)
Changes in self-efficacy. Nineteen of the questionnaire items were related to the construct of selfefficacy, addressing the participants' beliefs about their knowledge of the subject matter and their beliefs about their skills as pronunciation teachers. The response data met the assumptions for parametric tests, so a mixed ANOVA was conducted with time and group as factors. The output revealed significant main effects for time, $F(1,31)=6.308, p=.017$, and group, $F(1,31)=5.770, p=$ .022 , but no interaction effect. As shown in Figure 1, the treatment group started out with a higher self-efficacy mean $(\mathrm{M}=3.81, \mathrm{SD}=0.81)$ than the comparison group and increased more over time $(\mathrm{M}=4.15, \mathrm{SD}=0.73)$. The comparison group had a less marked increase in self-efficacy means from Time $1(\mathrm{M}=3.40, \mathrm{SD}=.50)$ to Time $2(\mathrm{M}=3.51, \mathrm{SD}=.57)$. The effect size of the change was greater for the treatment group, $d=-0.640$, than the comparison group, $d=-0.225$. The first effect size can be considered moderate, while the second one is small (Cohen, 1988). 


\section{Table 6}

Beliefs about Pronunciation Teaching and Learning with Significant Results

\begin{tabular}{|c|c|c|c|c|c|c|c|c|c|c|c|c|c|c|c|c|}
\hline & \multicolumn{8}{|c|}{ Treatment Group } & \multicolumn{8}{|c|}{ Comparison Group } \\
\hline & \multicolumn{4}{|c|}{ Time 1} & \multicolumn{4}{|c|}{ Time 2} & \multicolumn{4}{|c|}{ Time 1} & \multicolumn{4}{|c|}{ Time 2} \\
\hline & $\mathrm{D}$ & $\mathrm{U}$ & $\mathrm{A}$ & M & $\mathrm{D}$ & $\mathrm{U}$ & $\mathrm{A}$ & M & $\mathrm{D}$ & $\mathrm{U}$ & A & M & $\mathrm{D}$ & $\mathrm{U}$ & $\mathrm{A}$ & M \\
\hline $\begin{array}{l}\text { a. Teaching pronunciation } \\
\text { is often unnecessary, as } \\
\text { most learners are able to } \\
\text { pick up on pronunciation } \\
\text { when frequently exposed } \\
\text { to good language input. }\end{array}$ & $\begin{array}{l}14 \\
82.4\end{array}$ & 0 & $\begin{array}{l}3 \\
17.6\end{array}$ & 2 & $\begin{array}{l}14 \\
77.8\end{array}$ & $\begin{array}{l}2 \\
11.1\end{array}$ & $\begin{array}{l}2 \\
11.1\end{array}$ & 1 & $\begin{array}{l}11 \\
73.3\end{array}$ & 0 & $\begin{array}{l}4 \\
26.7\end{array}$ & 2 & $\begin{array}{l}5 \\
33.3\end{array}$ & $\begin{array}{l}5 \\
33.3\end{array}$ & $\begin{array}{l}5 \\
33.3\end{array}$ & 3 \\
\hline $\begin{array}{l}\text { k. Some individuals } \\
\text { resist changing their } \\
\text { pronunciation in order to } \\
\text { maintain their identity. }\end{array}$ & $\begin{array}{l}3 \\
16.7\end{array}$ & $\begin{array}{l}2 \\
11.1\end{array}$ & $\begin{array}{l}13 \\
72.2\end{array}$ & 5 & $\begin{array}{l}1 \\
5.6\end{array}$ & $\begin{array}{l}4 \\
22.2\end{array}$ & $\begin{array}{l}13 \\
72.2\end{array}$ & 4 & $\begin{array}{l}3 \\
20\end{array}$ & $\begin{array}{l}6 \\
40\end{array}$ & $\begin{array}{l}6 \\
40\end{array}$ & 3 & $\begin{array}{l}3 \\
20\end{array}$ & $\begin{array}{l}4 \\
26.7\end{array}$ & $\begin{array}{l}8 \\
53.3\end{array}$ & 4 \\
\hline $\begin{array}{l}\text { m. It is important to } \\
\text { know phonology (i.e., the } \\
\text { rules of pronunciation) } \\
\text { in order to teach English } \\
\text { pronunciation. }^{a}\end{array}$ & 0 & $\begin{array}{l}1 \\
5.6\end{array}$ & $\begin{array}{l}17 \\
94.4\end{array}$ & 5 & $\begin{array}{l}1 \\
5.9\end{array}$ & $\begin{array}{l}1 \\
5.9\end{array}$ & $\begin{array}{l}15 \\
88.2\end{array}$ & 6 & $\begin{array}{l}2 \\
13.3\end{array}$ & $\begin{array}{l}3 \\
20\end{array}$ & $\begin{array}{l}10 \\
66.7\end{array}$ & 4 & $\begin{array}{l}2 \\
13.3\end{array}$ & $\begin{array}{l}4 \\
26.7\end{array}$ & $\begin{array}{l}9 \\
60\end{array}$ & 4 \\
\hline $\begin{array}{l}\text { o. Teaching pronunciation } \\
\text { is boring. }{ }^{a b}\end{array}$ & $\begin{array}{l}17 \\
94.4\end{array}$ & 0 & $\begin{array}{l}1 \\
5.6\end{array}$ & 1 & $\begin{array}{l}16 \\
88.9\end{array}$ & $\begin{array}{l}1 \\
5.6\end{array}$ & $\begin{array}{l}1 \\
5.6\end{array}$ & 1 & $\begin{array}{l}10 \\
66.7\end{array}$ & $\begin{array}{l}3 \\
20\end{array}$ & $\begin{array}{l}2 \\
13.3\end{array}$ & 2 & $\begin{array}{l}7 \\
46.7\end{array}$ & $\begin{array}{l}3 \\
20\end{array}$ & $\begin{array}{l}5 \\
33.3\end{array}$ & 3 \\
\hline $\begin{array}{l}\text { s. Learners benefit from } \\
\text { paying conscious attention } \\
\text { to the input and becoming } \\
\text { aware of how different } \\
\text { features are produced. }{ }^{a c}\end{array}$ & 0 & $\begin{array}{l}4 \\
22.2\end{array}$ & $\begin{array}{l}14 \\
77.8\end{array}$ & 4 & $\begin{array}{l}1 \\
5.6\end{array}$ & $\begin{array}{l}2 \\
11.1\end{array}$ & $\begin{array}{l}15 \\
83.3\end{array}$ & 5 & 0 & $\begin{array}{l}4 \\
26.7\end{array}$ & $\begin{array}{l}11 \\
73.3\end{array}$ & 5 & $\begin{array}{l}1 \\
6.7\end{array}$ & $\begin{array}{l}4 \\
26.7\end{array}$ & $\begin{array}{l}10 \\
66.7\end{array}$ & 4 \\
\hline
\end{tabular}

Note. $\mathrm{D}=$ Disagree; $\mathrm{U}=$ Unsure or neutral; $\mathrm{A}=$ Agree;

$\mathrm{M}=$ Median

Content of unshaded cells $=$ Count and percentage

${ }^{a}$ Significant difference between groups at Time $2(p<$ $.05)$

${ }^{b}$ Significant difference between groups at Time $1(p<$ $.05)$

'Significant difference from Time 1 to Time 2 for the comparison group $(p<.05)$

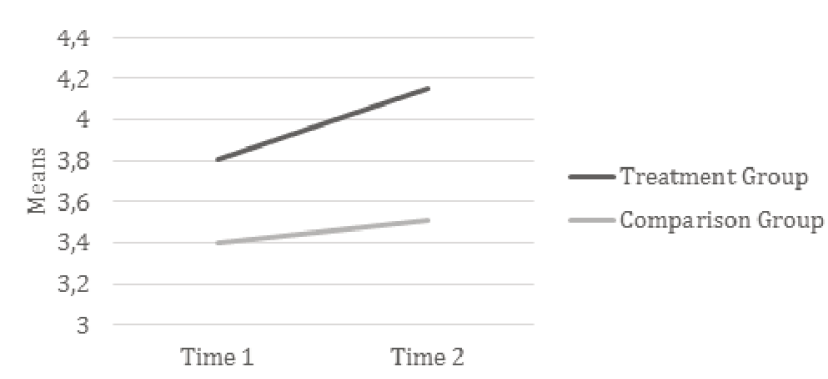

Figure 1. Self-efficacy changes from Time 1 to Time 2.
The interview data suggest that the phonology course also helped the participants become more aware of their limitations. For example, native English speaker Margaret confessed she initially felt "a bit arrogant" because she had been "blessed with wellspoken parents". With the course, she realized that was not enough and there was much more to teaching pronunciation than being able to model it properly: 
somebody needs to teach you what your mouth is doing, which most people are completely unaware of (...). And you don't have to be a native speaker to do that.

Leslie and Lynn, also NSs, expressed some concern that they were not always able to consciously identify pronunciation sounds and patterns. For example, they had a hard time identifying stress in an utterance, even though they could produce it. NNSs Amanda and Parvin gained awareness of foreign aspects of their own pronunciation. Amanda, whom the researcher thought had the most noticeable accent, was the only interviewed participant who believed the course made her less confident in her ability to teach pronunciation in the future. She explained that she became aware of everything she needs to improve in her own pronunciation. She also said during the interview that she wished the phonology course had been structured in two sessions and that NNSs had been given the chance to work on their own pronunciation problems first. The other two NNSs, Parvin and Christine, had generally native-like pronunciation, yet Parvin said the course made her realize that she had some "occasional slips", as she put it. She added, "I did become more conscious and more aware of maybe the slight differences in pronunciation that I have with the native speakers..." "You know, (the course) made me self-aware. It was total self-discovery."

Almost all of the interview participants reported feeling anxious or worried at some point during the course about having to teach the pronunciation tutorials. However, several of them also mentioned aspects of the course that helped prepare them for the tutorials and increase their confidence. Christine said it was "very beneficial" and "eye-opening" to have the professor explain to them what to do in a lesson, give them the course pack, and demonstrate the diagnostic test. Kassim also referred to the sample pronunciation activities given by the professor as "very helpful". For Leslie, it was learning the theory that helped her feel more confident: "I felt more confident (...) than I thought I would going into it, because of the course, because I've been shown that there were issues that could be caught and stuff like that". Similarly, Jennifer reported increasing self-efficacy as she went through the course:

At the beginning of the class when he mentioned about, you know, the portfolio, oh my God, the stress, the nerves, I was like, "Ugh! How am I gonna do this? I don't know anything about this course". And so I was like, "You know, I think I can do it, but we'll see, we'll see". And then by the end I was like, "No, I got this" (laughs).

Further findings. It was not only what was taught in the course that influenced the participants' cognitions, however. For the NS participants, interactions with NNSs throughout the course also seemed to have an important role. Margaret reported being very positively impressed with the teaching skills of her tutorial partner Parvin, which served as confirmation for her that being a NS was not necessary to teach pronunciation. Leslie said that she noticed from the beginning of the term that her NNS classmates had learned more about English pronunciation in school, whereas she was learning it for the first time. This led her to have feelings of inferiority. Similarly, Kassim talked about a NNS classmate who impressed him at first with his technical knowledge of pronunciation, because he had already learned it in a classroom setting. Over time, however, Kassim noticed that this classmate had difficulty applying what he knew to his own pronunciation, which led him to believe that NSs are better suited to teach pronunciation. Lynn and Jennifer also talked about classmates whose pronunciation was difficult to understand and wondered how that would affect their teaching. Even so, at Time 2 Jennifer disagreed more that NSs are better suited to teach pronunciation. The fact that three out of four of her professors that term were NNSs caused this change, as she was very impressed with their level of English and the quality of their teaching.

\section{Cognition Changes After Teaching}

The third research question inquired about further cognition changes that may have taken place after the pronunciation teaching practicum (Time 3 ) and how 
they are connected to the course or the practicum. This question will be answered from the interview data exclusively.

Changes in beliefs about pronunciation teaching and learning. The cognitions of the interviewees about pronunciation teaching and learning did not seem to change much after the practicum. In most cases, they would mention experiences from the tutorials to back up opinions they had already expressed in the questionnaires. Yet most participants mentioned at least one change that took place during or after the tutorials. In response to the statement "English sounds are easier to teach than global aspects like stress, rhythm, and intonation", Amanda first agreed (Time 1), then disagreed (Time 2). When asked about this change in her interview, she mentioned that she agreed with the statement again after the tutorials (Time 3). Kassim said that before the tutorials he thought pronunciation was too complicated to be taught, but he realized afterwards that it is very teachable. Christine was unsure or neutral at first, but after the tutorials she said she "tended to agree" that knowledge of phonology is important in order to teach pronunciation. She explained that it is easier to know the rules to be able to explain them to students. Furthermore, her response to the statement "Teaching pronunciation is boring", which had gone from "tend to agree" (Time 1) to "unsure or neutral" (Time 2), changed again at Time 3. She said teaching the tutorials was not boring, but interesting and enjoyable. Similarly, Parvin was surprised at how exciting it was to teach pronunciation, even though she did not find it particularly boring before. Finally, interacting with her student made Leslie realize how important it can be for ESL learners to sound native-like, something she was not aware of. As can be seen, the few cognition changes related to pronunciation teaching and learning that took place after the tutorials varied from participant to participant.

Changes in self-efficacy. The interviewed participants changed their answers to several questions related to self-efficacy after the practicum. In all but one case, their new answers revealed increased feelings of self-efficacy. Kassim went from agreeing with the statement "I find pronunciation a difficult topic to teach" at Times 1 and 2 to disagreeing with it completely.
Likewise, Margaret said teaching pronunciation was not as difficult as she thought it would be before trying it. Margaret, Kassim, and Christine reported becoming more confident or less anxious about teaching pronunciation in the future after the experience:
"If I had to go teach right now I think I would feel more confident about teaching pronunciation (than grammar), just because I've done it now." (Margaret)
"I'm not afraid of having to teach pronunciation. In fact, I'm excited that that's something that I'm able to do." (Kassim)
"...if I had to do what we did for this class again, then I would probably feel more comfortable. Just because I’ve done it once." (Christine)

Like Margaret and Christine, Jennifer also felt more confident about teaching pronunciation in the future because it would not be her first time:

\begin{abstract}
(The tutorials) definitely helped in giving me confidence in giving some kind of pronunciation-related lesson in future classes. (...) I have the practice, if you will. I got the chance to, like, test the waters. (...) I'm always shy and anxious the first time I do something, so it, you know, broke the ice.
\end{abstract}

Five participants (Amanda, Kassim, Christine, Parvin, and Leslie) mentioned that they noticed improvement in their learners' speech throughout the tutorials, which indicated to them that they were doing well as pronunciation instructors. The only instance in which self-efficacy seemed to decrease because of the tutorial experience was Christine's response to the statement "I am afraid that students might 'catch' me making pronunciation mistakes when I teach", which had changed from "tend to disagree" to "unsure or neutral" from the first to the second questionnaire. In her interview, Christine mentioned that if she had to answer the question again, she would say "tend to agree". She explained that she made a mistake in one of her tutorial lessons on vowels and that this made her realize mistakes could happen.

Further findings. The interview data indicated that the phonology course might not have focused 
enough on the use of communicative activities to teach pronunciation. During the last block of the course, the instructor did talk about the importance of moving from more controlled to less controlled pronunciation practice (following Celce-Murcia, Brinton, \& Goodwin, 2010), and he also provided samples of guided and communicative activities. However, it seemed like the participants needed more examples and guidance on how to use these types of activities. Amanda observed that "when you look at the course pack, it's a lot of drillings and repetitions", which led her to believe that communicative activities were not that helpful for teaching pronunciation. Similarly, Parvin said that her preparation for the tutorials "was all about explicit phonology teaching" and not about meaningful communication.

The participants also mentioned a few challenges that they faced when trying to implement more communicative activities. Christine, Jennifer, and Lynn reported being surprised by their learners' lack of vocabulary. In addition, Lynn said she found it hard to get her learner to talk and felt she needed more teaching experience with communicative activities. Finally, pronunciation mistakes during authentic communication posed a challenge for Kassim and Lynn, as they did not know how to address them with their learners.

In sum, the findings suggested that general TESL training and specialized training in phonology and pronunciation pedagogy affect TC differently. While most of the participants' pronunciation-related cognitions did not change significantly over time, two months of specialized theoretical training led the treatment group to value explicit pronunciation teaching significantly more than the comparison group and was more effective at increasing the participants' self-efficacy as pronunciation teachers. A short practicum at the end of the course further increased self-efficacy, but did not seem to generate considerable changes in other cognitions. Further findings pointed to the relevant role of NS-NNS interactions in shaping TC and to the need for more training on guided and communicative pronunciation teaching techniques.

\section{Discussion}

The first two research questions inquired about potential changes to pronunciation-related TC after the taught portion of an undergraduate course in phonology and pronunciation teaching, how these changes related to the course content and activities, and how they compared to those experienced by student teachers who did not receive specialized training in the area. The analysis of the questionnaire data revealed that the treatment group had significantly more favorable views of explicit pronunciation teaching and learning than the comparison group at Time 2. Moreover, the treatment group experienced a larger increase in selfefficacy from Time 1 to Time 2. The interview data indicated that the treatment participants' awareness of their limitations also increased because of the course.

The different kinds of instruction each group received may explain the cognition differences observed between the groups towards the end of the term. The treatment group had an entire course dedicated to phonology and pronunciation pedagogy, which emphasized the importance of explicit teaching and learning of pronunciation and provided them with guidance, techniques, and examples on how to teach pronunciation. The comparison group, on the other hand, only received general instruction on L2 education. The course they did on L2 education analyzed ESL teaching methods and approaches from a historical and analytical perspective, so there might have been an emphasis on communicative language teaching (CLT) as the most current approach, and it is possible that the students connected explicit teaching of pronunciation to past and limited approaches such as the audiolingual method. Lack of specific training may also be the reason the comparison group's self-efficacy as prospective pronunciation teachers did not improve as much. The interview data seemed to confirm the connection between the treatment participants' cognitions and the instruction received, as suggested by the many references made to the phonology course and the professor. The cognitions of NS teachers were also influenced by their interactions with and observations of the NNSs in the course. 
These results are generally in line with those of Baker (2011a), Burri (2015a, 2015b), and Burri et al. (2017), who also found that a specialized course in pronunciation pedagogy had an important role in shaping TC. However, some noticeable differences from the findings of Burri's study should be mentioned. While in Burri (2015b) NS teachers came to have more positive views of NNS teachers, that was not always the case in this study. It is possible that the NNSs in Burri's study, who were graduate students and more experienced ESL teachers, simply had higher proficiency levels or even higher confidence in speaking English than some of the students in the undergraduate course here studied. Most likely, however, Burri's participants became more open to nonnative models of pronunciation because one of the course objectives was to develop an appreciation of different English varieties and accents. The course included regular comparisons of accents and discussions on World Englishes (Burri, 2015a), something that was not present in the pronunciation course here analyzed.

Another difference is that Burri (2015b) suggested links between NNSs' cognition development and their sense of pronunciation improvement. Although none of the three NNSs interviewed in this study reported a sense of improvement, they still became more aware of their own speech and changed several of their pronunciationrelated cognitions. Nonetheless, the only NNS who struggled with some aspects of English pronunciation did not experience an increase in self-efficacy and wished she had had the opportunity to work on her own pronunciation during the course. It is therefore possible that, for her and other NNSs like her, experiencing pronunciation improvement or at least having pedagogical attention given to their pronunciation may be necessary for confidence to increase.

The fact that the NNSs in Burri (2015b) believed they improved their pronunciation while those in this study did not may be attributed to the different class structures. In this study, most of the training in pronunciation teaching activities and techniques was received at the end of the course. In Burri's study, each of the instructor's weekly lectures was followed by a training session in a pronunciation teaching technique. This may have given NNSs a chance not only to become aware of the pronunciation features covered in the lectures, but also to practice them by applying the teaching techniques learned throughout the course. Future research should address how courses in pronunciation pedagogy can provide better support to the growing number of ESL/EFL teachers who are NNSs, given that language difficulties negatively affect these teachers' self-efficacy (Reves \& Medgyes, 1994; Samimy \& BruttGriffler, 1999) and that insecurity about the quality of their own pronunciation might make them reluctant to teach pronunciation (Murphy, 2014).

The third research question was "What further cognition changes (if any) take place after the pronunciation teaching practicum, and how are these changes linked to the course or the practicum?" The findings of the interviews indicated that the practicum, albeit short, contributed to further increase the selfefficacy of most of the interviewed students. Simply having tried to teach pronunciation for the first time and seeing their learners' progress were important factors. However, in contrast to what was found by Bateman (2008) and Mattheoudakis (2007), very few changes were observed in the participants' beliefs about teaching and learning from Time 2 to Time 3. Given that the phonology course was very teachingoriented and evidence-based, it is possible that what they learned was generally in line with the teaching reality they experienced and that the practicum solidified their beliefs. Another possibility is that the practicum was too short to generate substantial changes to these beliefs.

While the phonology course was found to increase the participants' overall confidence in their ability to teach pronunciation, the data indicated that they might not have been fully prepared to use more communicative pronunciation activities in their lessons. This problem may be common to other phonology and pronunciation pedagogy courses, as Baker (2014) noticed that even experienced teachers who had undergone specialized training in the field tended to use only controlled activities in class. Similarly, Burri et al. (2017) found that student teachers had a preference for controlled activities at the end of a graduate course 
in pronunciation pedagogy. This is concerning because ESL students who learn target sounds or patterns in controlled activities (e.g., reading, repetition, mechanical drills) may not transfer what they learned to their communicative production (Elliott, 1997). Although the phonology course here studied did not neglect guided and communicative teaching techniques (as was also the case in Burri et al., 2017), the use of such techniques in class may be more challenging and less predictable than the use of controlled ones, thus requiring more attention during training.

\section{Conclusion and Future Directions}

Overall, the findings of this study suggest that specific training that combines an introduction to English phonology and guidelines for pronunciation teaching has a positive impact on pre-service ESL teachers' cognitions. It is considerably more effective than general TESL instruction in helping teachers develop favorable views of explicit pronunciation teaching and confidence in their ability to teach pronunciation. Including a short practicum as part of the training has the potential of further enhancing selfefficacy. These results are promising, given that lack of confidence in teaching pronunciation is a common problem reported by many ESL/EFL teachers which can lead to avoidance of pronunciation instruction (Couper, 2016; Foote et al., 2011; Macdonald, 2002). To the author's knowledge, this was the first study on pronunciation teacher education to include a comparison group, making it easier to attribute the differences found in TC to pronunciation training.

The findings here presented should be interpreted in light of the limitations of the study, which can be addressed in future research. First, it would be helpful if future studies included a measure of participants' cognitions before starting training. In this study, the first questionnaire was completed two to four weeks into the term, so it is not clear which cognitions expressed in the pre-questionnaire (and how much of them) had been influenced by the participants' first weeks of TESL instruction. Second, the use of random sampling of participants would be ideal, as there is always a possibility that the students who self-selected for this study differed systematically from those who did not (e.g., they may have been more interested in pronunciation than the average TESL student). Furthermore, interviewing all treatment participants rather than a subset of them would control for the possibility that the interview findings are not representative of the whole sample. Besides addressing these limitations, future research can also include delayed post-measures that investigate whether and how pronunciation-related cognitions change long after training (e.g., by the end of the TESL program). Finally, it would be interesting to explore how the teachers' beliefs play out in the classroom once they start teaching. Given that TC affects behavior in class, it is reasonable to believe that trained teachers will be more likely than non-trained teachers to integrate pronunciation instruction into their general ESL classes in the future. However, this is an empirical question that requires further investigation.

\section{Acknowledgements}

This research was supported by a doctoral scholarship from CAPES, Brazil [grant no. 0369/12-8]. I would like to thank Pavel Trofimovich, who contributed to the conception of the study and reviewed the data collection instruments. I am also grateful to Sara Kennedy for her valuable feedback on earlier drafts of this paper.

\section{Note}

1. Please contact the author to receive the other versions of the questionnaire.

\section{References}

Albini, A., \& Kluge, D. (2011). Professores de inglês da rede pública paranaense e o ensino da pronúncia [Public school English teachers from Paraná and the teaching of pronunciation]. Revista de Letras DACEX/ UTFPR, 1, 1-12.

Ashton, P. T., \& Webb, R. B. (1986). Making a difference: Teachers' sense of efficacy and student achievement. New York: Longman.

Baker, A. (2011a). ESL teachers and pronunciation pedagogy: Exploring the development of teachers' cognitions and classroom practices. In J. Levis \& K. LeVelle (Eds.), Proceedings of the 2nd Pronunciation 
in Second Language Learning and Teaching Conference (pp. 82-94). Aimes, IA: Iowa State University.

Baker, A. (2011b). Pronunciation Pedagogy: Second Language Teacher Cognition and Practice. Georgia State University. Retrieved from http://digitalarchive. gsu.edu/alesl_diss/16/

Baker, A. (2014). Exploring teachers' knowledge of second language pronunciation techniques: Teacher cognitions, observed classroom practices, and student perceptions. TESOL Quarterly, 48(1), 136-163.

Bandura, A. (1977). Self-efficacy: Toward a unifying theory of behavioral change. Psychological Review, 84(2), 191-215.

Bateman, B. (2008). Student teachers' attitudes and beliefs about using the target language in the classroom. Foreign Language Annals, 41(1), 11-28.

Borg, S. (2003). Teacher cognition in language teaching: A review of research on what language teachers think, know, believe, and do. Language Teaching, 36(2), 81109.

Borg, S. (2006). Teacher cognition and language education: Research and practice. London: Continuum.

Breitkreutz, J., Derwing, T. M., \& Rossiter, M. J. (2001). Pronunciation teaching practices in Canada. TESL Canada Journal, 19(1), 51-61.

Burgess, J., \& Spencer, S. (2000). Phonology and pronunciation in integrated language teaching and teacher education. System, 28(2), 191-215.

Burns, A. (2006). Integrating research and professional development on pronunciation teaching in a national adult ESL program. TESL Reporter, 39(2), 34-41.

Burri, M. (2015a). "My perspective changed dramatically": A case for preparing L2 instructors to teach pronunciation. English Australia Journal, 31(1), 19-37.

Burri, M. (2015b). Student teachers' cognition about L2 pronunciation instruction: A case study. Australian Journal of Teacher Education, 40(10), 66-87.

Burri, M., Baker, A., \& Chen, H. (2017). "I feel like having a nervous breakdown": Pre-service and in-service teachers' developing beliefs and knowledge about pronunciation instruction. Journal of Second Language Pronunciation, 3(1), 109-135.

Buss, L. (2013). Pronunciation from the perspective of pre-service EFL teachers: An analysis of internship reports. In J. Levis \& K. LeVelle (Eds.), Proceedings of the 4th Pronunciation in Second Language Learning and Teaching Conference (pp. 255-264). Ames, IA: Iowa State University.
Buss, L. (2016). Beliefs and practices of Brazilian EFL teachers regarding pronunciation. Language Teaching Research, 20(5), 619-637.

Celce-Murcia, M., Brinton, D., \& Goodwin, J. (2010). Teaching pronunciation: A course book and reference guide (2nd ed.). New York: Cambridge University Press.

Cohen, J. (1988). Statistical power analysis for the behavioral sciences (2nd ed.). Hillsdale, NJ: Lawrence Earlbaum Associates.

Couper, G. (2016). Teacher cognition of pronunciation teaching amongst English language teachers in Uruguay. Journal of Second Language Pronunciation, 2(1), 29-55.

Derwing, T. M., \& Munro, M. J. (2005). Second language accent and pronunciation teaching: A research-based approach. TESOL Quarterly, 39(3), 379-397

Elliott, A. R. (1997). On the teaching and acquisition of pronunciation within a communicative approach. Hispania, 80(1), 95.

Foote, J., Holtby, A., \& Derwing, T. M. (2011). Survey of the teaching of pronunciation in adult ESL programs in Canada, 2010. TESL Canada Journal, 29(1), 1-22.

Ghaith, G., \& Yaghi, H. (1997). Relationships among experience, teacher efficacy, and attitudes toward the implementation of instructional innovation. Teaching and Teacher Education, 13(4), 451-458.

Henderson, A. (2013). The English Pronunciation Teaching in Europe Survey: Initial results and useful insights for collaborative work. In E. Waniek-Klimczak \& L. R. Shockey (Eds.), Teaching and researching English accents in native and non-native speakers (pp. 123136). Berlin, Heidelberg: Springer Berlin Heidelberg.

Hismanoglu, M., \& Hismanoglu, S. (2010). Language teachers' preferences of pronunciation teaching techniques: traditional or modern? Procedia - Social and Behavioral Sciences, 2(2), 983-989.

Horwitz, E. (1985). Using student beliefs about language learning and teaching in the foreign language methods course. Foreign Language Annals, 18(4), 333-340.

Jenkins, J. (2005). Implementing an international approach to English pronunciation: The role of teacher attitudes and identity. TESOL Quarterly, 39(3), 535-543.

Lightbown, P., \& Spada, N. (1995). How languages are learned. Oxford: Oxford University Press.

Macdonald, S. (2002). Pronunciation: Views and practices of reluctant teachers. Prospect, 17(3), 3-18. 
MacDonald, M., Badger, R., \& White, G. (2001). Changing values: what use are theories of language learning and teaching? Teaching and Teacher Education, 17(8), 949963.

Mattheoudakis, M. (2007). Tracking changes in preservice EFL teacher beliefs in Greece: A longitudinal study. Teaching and Teacher Education, 23(8), 12721288.

Miles, M. B., Huberman, A. M., \& Saldaña, J. (2014). Qualitative data analysis: A methods sourcebook (3rd ed.). Thousand Oaks: Sage Publications.

Murphy, J. (2014). Teacher training programs provide adequate preparation in how to teach pronunciation. In L. Grant (Ed.), Pronunciation myths: Applying second language research to classroom teaching (pp. 188-219). Ann Arbor, MI: The University of Michigan Press.

Reves, T., \& Medgyes, P. (1994). The non-native English speaking EFL/ESL teacher's self-image: An international survey. System, 22(3), 353-367.

Roberts, J., \& Henson, R. (2000). Self-efficacy Teaching and Knowledge Instrument for Science Teachers (SETAKIST): A proposal for a new efficacy instrument. Paper presented at the Annual Meeting of the MidSouth Educational Research Association (28th, Bowling Green, KY, November 17-19, 2000).

Samimy, K., \& Brutt-Griffler, J. (1999). Perceptions of NNS students in a graduate TESOL program. In G. Braine (Ed.), Non-native educators in English language teaching (pp. 129-146). Mahwah, NJ: Lawrence Erlbaum.

Sifakis, N., \& Sougari, A. (2005). Pronunciation issues and EIL pedagogy in the periphery: A survey of Greek state school teachers' beliefs. TESOL Quarterly, 39(3), 467-488.

Smylie, M. A. (1988). The enhancement function of staff development: Organizational and psychological antecedents to individual teacher change. American Educational Research Journal, 25(1), 1-30.

Tergujeff, E. (2012a). English pronunciation teaching: Four case studies from Finland. Journal of Language Teaching and Research, 3(4), 599-607.

. (2012b). The English Pronunciation Teaching in Europe Survey: Finland. Apples, 6(1), 29-45.

Timmis, I. (2002). Native-speaker norms and international English: a classroom view. ELT Journal, 56(3), 240-249.

Tschannen-Moran, M., Hoy, a. W., \& Hoy, W. K. (1998). Teacher efficacy: Its meaning and measure. Review of Educational Research, 68(2), 202-248. 


\section{APPENDIX A}

Treatment Group Native-Speaker Questionnaire - Time 1

\section{SECTION I - Background Information}

1. Name: 2. Gender: Male $\square$ Female

3. Date of birth (DD/MM/YY): 4. Birthplace (city, country):

5. Email: 6. Date you started the program (DD/MM/YY)

7. What do you consider to be your native language(s)?

8. Were you exposed to this (these) language(s) since birth?

9. If not, at what age did you start learning English?

10. Please rate your ability to speak, listen to, read and write English from 1 (extremely poor) to 9 (extremely fluent). Circle the appropriate number.

\begin{tabular}{l|l|l|l}
\hline Speaking & Listening & Reading & Writing \\
\hline 123456789 & 123456789 & 123456789 & 123456789 \\
\hline
\end{tabular}

11. If you are bilingual, please rate your ability to speak, listen to, read and write your second native language from 1 (extremely poor) to 9 (extremely fluent). Circle the appropriate number.

\begin{tabular}{l|l|l|l}
\hline Speaking & Listening & Reading & Writing \\
\hline 123456789 & 1234456789 & 123456789 & 123456789 \\
\hline
\end{tabular}

12. Did you receive any instruction on how to teach ESL or English pronunciation prior to entering the TESL program? If yes, please indicate when, where, for how long, and the kind of instruction received.

13. What do you hope to accomplish with this TESL program? 


\section{SECTION II - Beliefs about Pronunciation}

1. How important is it for ESL instructors to teach the following knowledge and skills? Please circle a number

\begin{tabular}{c|c|c|cccc}
\hline $\begin{array}{c}\text { No } \\
\text { importance }\end{array}$ & $\begin{array}{c}\text { Almost no } \\
\text { importance }\end{array}$ & $\begin{array}{c}\text { Little } \\
\text { importance }\end{array}$ & $\begin{array}{c}\text { Unsure or } \\
\text { neutral }\end{array}$ & $\begin{array}{c}\text { Moderate } \\
\text { importance }\end{array}$ & $\begin{array}{c}\text { Large } \\
\text { importance }\end{array}$ & $\begin{array}{c}\text { Extreme } \\
\text { importance }\end{array}$ \\
\hline $\mathbf{1}$ & $\mathbf{2}$ & $\mathbf{3}$ & $\mathbf{4}$ & $\mathbf{5}$ & $\mathbf{6}$ & $\mathbf{7}$ \\
\hline
\end{tabular}

\begin{tabular}{|c|c|c|c|c|c|c|c|c|c|c|c|}
\hline a. Reading strategies & 1233 & 3 & 4 & & & e. Fluency and pronunciation & 12 & 3 & & & \\
\hline b. Listening strategies & 123 & 3 & 4 & 5 & & f. Grammar & 12 & 3 & & 5 & 7 \\
\hline c. Vocabulary & 1233 & 3 & 4 & 5 & & g. Writing skills & 12 & 3 & & & 7 \\
\hline d. Conversational skills & 123 & 3 & 4 & 5 & 0 & h. Culture of English-speaking countries & 12 & 3 & & 5 & 7 \\
\hline
\end{tabular}

2. Please indicate your level of agreement with the following statements by circling a number.

\begin{tabular}{c|c|c|cccc}
\hline $\begin{array}{c}\text { Strongly } \\
\text { disagree }\end{array}$ & Disagree & Tend to disagree & $\begin{array}{c}\text { Unsure or } \\
\text { neutral }\end{array}$ & Tend to agree & Agree & Strongly agree \\
\hline $\mathbf{1}$ & $\mathbf{2}$ & $\mathbf{3}$ & $\mathbf{4}$ & $\mathbf{5}$ & $\mathbf{6}$ & $\mathbf{7}$ \\
\hline
\end{tabular}

a. Teaching pronunciation is often unnecessary, as most learners are able to pick up on pronunciation when frequently exposed to good language input.

b. A heavy accent is a cause of discrimination against nonnative speakers.

c. Pronunciation is not really teachable - you are either naturally good at it or not.

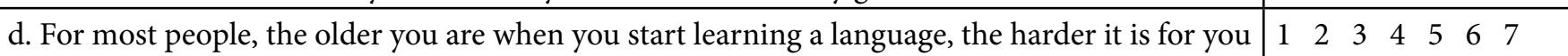
to acquire native-like pronunciation.

e. There is a relationship between learners' perception and production of English speech.

$\mathrm{f}$. The goal of pronunciation teaching should be to eliminate, as much as possible, foreign accent.

g. It is possible to teach pronunciation communicatively (i.e., through meaningful language use).

h. When learners are aware of pronunciation rules, it can help them improve their pronunciation.

i. Native speakers should be the model for pronunciation teaching.

j. Some pronunciation errors have a greater impact on intelligibility (i.e., understanding a speaker) than others.

$\mathrm{k}$. Some individuals resist changing their pronunciation in order to maintain their identity.

1. Pronunciation is learned best by trying to imitate good models.

m. It is important to know phonology (i.e., the rules of pronunciation) in order to teach English pronunciation.

n. Pronunciation teaching should help make students comfortably intelligible to listeners.

o. Teaching pronunciation is boring.

p. ESL teachers should avoid correcting or pointing out pronunciation errors on the spot.

q. English sounds (e.g., the " $h$ " sound in the word "house") are easier to teach than global aspects like stress, rhythm and intonation.

r. Pronunciation instruction improves the accuracy of language production rather than communication on the whole.

$\begin{array}{lllllll}1 & 2 & 3 & 4 & 5 & 6 & 7\end{array}$ 


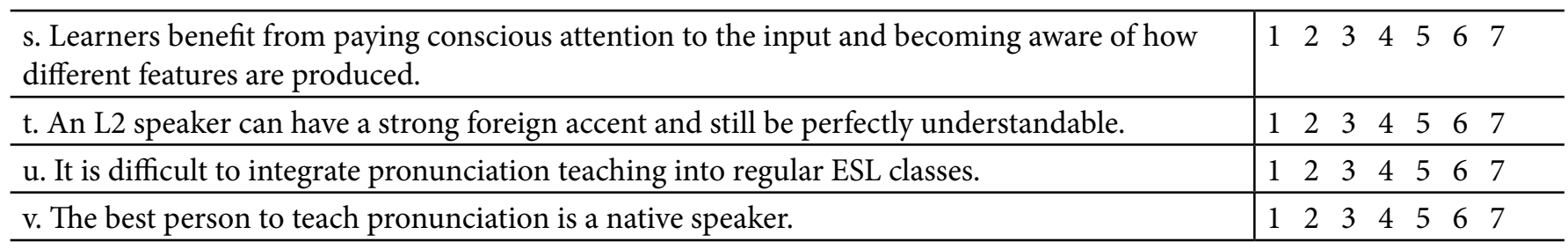

\section{SECTION III - Yourself as a Current or Prospective ESL Teacher}

1. Please indicate your level of agreement with the following statements by circling a number4

\begin{tabular}{|c|c|c|c|c|c|c|}
\hline $\begin{array}{l}\text { Strongly } \\
\text { disagree }\end{array}$ & Disagree & Tend to disagree & $\begin{array}{c}\text { Unsure or } \\
\text { neutral }\end{array}$ & Tend to agree & Agree & Strongly agree \\
\hline 1 & 2 & 3 & 4 & 5 & 6 & 7 \\
\hline
\end{tabular}

a. I don't have the necessary skills to teach pronunciation.

b. I can adequately produce English stress, rhythm and intonation patterns.

\begin{tabular}{l|lllllll} 
& 1 & 2 & 3 & 4 & 5 & 6 & 7 \\
\hline & 1 & 2 & 3 & 4 & 5 & 6 & 7 \\
\hline
\end{tabular}

c. I would feel uncomfortable if the professor observed my pronunciation tutorials at the end of $\begin{array}{llllllllllllll}1 & 2 & 3 & 4 & 5 & 6 & 7\end{array}$ the term.

d. If I try really hard, I can make even the most difficult or unmotivated student learn English pronunciation.

e. I can adequately produce English sounds (e.g., the "th" sound in "mother").

f. I know enough about English pronunciation to teach it effectively.

g. I wish I had received more instruction on English pronunciation as a learner.

h. I feel anxious about having to teach English pronunciation.

i. I know what to do to teach pronunciation effectively.

j. As a current or prospective ESL teacher, I feel inferior compared to my peers who are nonnative speakers of the language.

k. Even if I try very hard, I can never be an effective pronunciation teacher.

$\begin{array}{lllllll}1 & 2 & 3 & 4 & 5 & 6 & 7\end{array}$

l. I have to study more English phonology (i.e., the rules of pronunciation) to feel comfortable teaching pronunciation.

m. I am confident that as a teacher I can (or will be able to) help my students improve their pronunciation.

n. To be a good pronunciation teacher, I will need to work much harder than my peers who are nonnative English speakers.

o. I can (or will be able to) answer my students' questions about English pronunciation.

$\begin{array}{lllllll}1 & 2 & 3 & 4 & 5 & 6 & 7\end{array}$

$\begin{array}{lllllll}1 & 2 & 3 & 4 & 5 & 6 & 7\end{array}$

$\begin{array}{lllllll}1 & 2 & 3 & 4 & 5 & 6 & 7\end{array}$

$\begin{array}{lllllll}1 & 2 & 3 & 4 & 5 & 6 & 7\end{array}$

\begin{tabular}{lllllll}
1 & 2 & 3 & 4 & 5 & 6 & 7 \\
\hline
\end{tabular}

$\begin{array}{lllllll}1 & 2 & 3 & 4 & 5 & 6 & 7\end{array}$

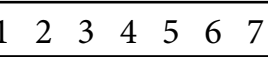

$\begin{array}{lllllll}1 & 2 & 3 & 4 & 5 & 6 & 7\end{array}$

$\begin{array}{lllllll}1 & 2 & 3 & 4 & 5 & 6 & 7\end{array}$

p. I find pronunciation a difficult topic to teach.

q. I need to improve my own pronunciation in English before I can teach it to others.

r. I know how to make students interested in pronunciation.

s. I am a good pronunciation model for ESL students.

t. I am (or will be) better at teaching grammar or vocabulary than pronunciation.

$\begin{array}{lllllll}1 & 2 & 3 & 4 & 5 & 6 & 7\end{array}$

u. I am afraid that students might "catch" me making pronunciation mistakes when I teach.

v. Overall, I have a good grasp of English pronunciation rules.

$\begin{array}{lllllll}1 & 2 & 3 & 4 & 5 & 6 & 7\end{array}$

$\begin{array}{lllllll}1 & 2 & 3 & 4 & 5 & 6 & 7\end{array}$

$\begin{array}{lllllll}1 & 2 & 3 & 4 & 5 & 6 & 7\end{array}$

$\begin{array}{lllllll}1 & 2 & 3 & 4 & 5 & 6 & 7\end{array}$

$\begin{array}{lllllll}1 & 2 & 3 & 4 & 5 & 6 & 7\end{array}$

$\begin{array}{lllllll}1 & 2 & 3 & 4 & 5 & 6 & 7\end{array}$

$\begin{array}{lllllll}1 & 2 & 3 & 4 & 5 & 6 & 7\end{array}$

$\begin{array}{lllllll}1 & 2 & 3 & 4 & 5 & 6 & 7\end{array}$ 


\section{SECTION IV - Further Opinions and Experiences}

1. Have you ever studied a second language? $\square \quad$ Yes $\square$ No (If not, please skip to \#6)

2. What language(s) have you studied?

3. As a second language learner, did you ever receive pronunciation instruction? $\square$ Yes $\quad \square \quad$ No

4. If yes, what types of activities and resources did your teachers use to teach pronunciation?

5. Do you think the pronunciation instruction you received was effective? Why?

6. For the pronunciation tutorials at the end of the semester, you and a classmate will be asked to teach pronunciation lessons to an ESL learner together. Would you feel more comfortable if this classmate (i.e., your co-teacher) was a native English speaker or a nonnative English speaker? Why?

7. Do you have any experience teaching English? $\square \quad$ Yes (Please answer the questions below) $\quad \square \quad$ No

8. If yes, for how long?

9. Where have you taught? Please mention the city and the type of institution (e.g., public school).

10. When you teach (taught), on average, approximately what percentage of your weekly class time is (was) dedicated to explicit pronunciation instruction?

11. What types of activities and resources do (did) you usually use to teach pronunciation? 


\section{APPENDIX B}

Questionnaire Results: Beliefs about Pronunciation Teaching and Learning

a. Teaching pronunciation is often unnecessary, as most learners are able to pick up on pronunciation when frequently exposed to good language input.

b. A heavy accent is a cause of discrimination against nonnative speakers.

c. Pronunciation is not really teachable - you are either naturally good at it or not.

d. For most people, the older you are when you start learning a language, the harder it is for you to acquire native-like pronunciation.

e. There is a relationship between learners' perception and production of English speech.

f. The goal of pronunciation teaching should be to eliminate, as much as possible, foreign accent.

g. It is possible to teach pronunciation communicatively (i.e., through meaningful language use).

h. When learners are aware of pronunciation rules, it can help them improve their pronunciation.

i. Native speakers should be the model for pronunciation teaching.

j. Some pronunciation errors have a greater impact on intelligibility (i.e., understanding a speaker) than others.

$\mathrm{k}$. Some individuals resist changing their pronunciation in order to maintain their identity.

\begin{tabular}{|c|c|c|c|c|c|c|c|c|c|c|c|c|c|c|c|}
\hline \multicolumn{8}{|c|}{ Treatment Group } & \multicolumn{8}{|c|}{ Comparison Group } \\
\hline \multicolumn{4}{|c|}{ Time 1} & \multicolumn{4}{|c|}{ Time 2} & \multicolumn{4}{|c|}{ Time 3} & \multicolumn{4}{|c|}{ Time 4} \\
\hline $\mathrm{D}$ & $\mathrm{U}$ & A & $\mathrm{M}$ & $\mathrm{D}$ & $\mathrm{U}$ & A & $\mathrm{M}$ & $\mathrm{D}$ & $\mathrm{U}$ & A & $\mathrm{M}$ & $\mathrm{D}$ & $\mathrm{U}$ & A & $\mathrm{M}$ \\
\hline 14 & 0 & 3 & 2 & 14 & 2 & 2 & 1 & 11 & 0 & 4 & 2 & 5 & 5 & 5 & 3 \\
\hline 82.4 & & 17.6 & & 77.8 & 11.1 & 11.1 & & 73.3 & & 26.7 & & 33.3 & 33.3 & 33.3 & \\
\hline 6 & 3 & 8 & 3 & 3 & 7 & 8 & 3 & 7 & 3 & 5 & 3 & 7 & 1 & 7 & 3 \\
\hline 35.3 & 17.6 & 47.1 & & 16.7 & 38.9 & 44.4 & & 46.7 & 20 & 33.3 & & 46.7 & 6.7 & 46.7 & \\
\hline 18 & 0 & 0 & 1 & 17 & 0 & 1 & 0.5 & 12 & 1 & 2 & 1 & 11 & 1 & 3 & 1 \\
\hline 100 & & & & 94.4 & & 5.6 & & 80 & 6.7 & 13.3 & & 73.3 & 6.7 & 20 & \\
\hline 3 & 1 & 14 & 4 & 1 & 1 & 16 & 5 & 0 & 1 & 14 & 5 & 0 & 2 & 13 & 5 \\
\hline 16.7 & 5.6 & 77.8 & & 5.6 & 5.6 & 88.9 & & & 6.7 & 93.3 & & & 13.3 & 86.7 & \\
\hline 2 & 4 & 12 & 4 & 1 & 2 & 15 & 4 & 0 & 5 & 10 & 4 & 1 & 1 & 13 & 5 \\
\hline 11.1 & 22.2 & 66.7 & & 5.6 & 11.1 & 83.3 & & & 33.3 & 66.7 & & 6.7 & 6.7 & 86.7 & \\
\hline 13 & 1 & 3 & 2 & 13 & 3 & 2 & 2 & 10 & 1 & 4 & 2 & 10 & 2 & 3 & 2 \\
\hline 76.5 & 5.9 & 17.6 & & 72.2 & 16.7 & 11.1 & & 66.7 & 6.7 & 26.7 & & 66.7 & 13.3 & 20 & \\
\hline 1 & 0 & 17 & 5 & 2 & 5 & 10 & 4 & 0 & 3 & 11 & 4.5 & 1 & 0 & 13 & 4.5 \\
\hline 5.6 & & 94.4 & & 11.8 & 29.4 & 58.8 & & & 21.4 & 78.6 & & 7.1 & & 92.9 & \\
\hline 0 & 2 & 15 & 5 & 0 & 2 & 16 & 5 & 1 & 3 & 11 & 5 & 1 & 1 & 13 & 5 \\
\hline & 11.8 & 88.2 & & & 11.1 & 88.9 & & 6.7 & 20 & 73.3 & & 6.7 & 6.7 & 86.7 & \\
\hline 4 & 3 & 11 & 4 & 4 & 5 & 9 & 3.5 & 1 & 3 & 11 & 4 & 3 & 7 & 5 & 3 \\
\hline 22.2 & 16.7 & 61.1 & & 22.2 & 27.8 & 50 & & 6.7 & 20 & 73.3 & & 20 & 46.7 & 33.3 & \\
\hline 1 & 2 & 15 & 5 & 0 & 1 & 17 & 5 & 2 & 1 & 12 & 5 & 1 & 2 & 12 & 5 \\
\hline 5.6 & 11.1 & 83.3 & & & 5.6 & 94.4 & & 13.3 & 6.7 & 80 & & 6.7 & 13.3 & 80 & \\
\hline 3 & 2 & 13 & 5 & 1 & 4 & 13 & 4 & 3 & 6 & 6 & 3 & 3 & 4 & 8 & 4 \\
\hline 16.7 & 11.1 & 72.2 & & 5.6 & 22.2 & 72.2 & & 20 & 40 & 40 & & 20 & 26.7 & 53.3 & \\
\hline
\end{tabular}




\begin{tabular}{|c|c|c|c|c|c|c|c|c|c|c|c|c|c|c|c|c|}
\hline $\begin{array}{l}\text { 1. Pronunciation is learned } \\
\text { best by trying to imitate good } \\
\text { models. }\end{array}$ & $\begin{array}{c}1 \\
5.6\end{array}$ & $\begin{array}{c}5 \\
27.8\end{array}$ & $\begin{array}{c}12 \\
66.7\end{array}$ & 4 & $\begin{array}{c}2 \\
11.1\end{array}$ & $\begin{array}{c}3 \\
16.7\end{array}$ & $\begin{array}{c}13 \\
72.2\end{array}$ & 4 & $\begin{array}{c}4 \\
26.7\end{array}$ & $\begin{array}{c}3 \\
20\end{array}$ & $\begin{array}{c}8 \\
53.3\end{array}$ & 4 & $\begin{array}{c}1 \\
6.7\end{array}$ & $\begin{array}{c}4 \\
26.7\end{array}$ & $\begin{array}{c}10 \\
66.7\end{array}$ & 4 \\
\hline $\begin{array}{l}\text { m. It is important to know } \\
\text { phonology (i.e., the rules of } \\
\text { pronunciation) in order to } \\
\text { teach English pronunciation. }\end{array}$ & 0 & $\begin{array}{c}1 \\
5.6\end{array}$ & $\begin{array}{c}17 \\
94.4\end{array}$ & 5 & $\begin{array}{c}1 \\
5.9\end{array}$ & $\begin{array}{c}1 \\
5.9\end{array}$ & $\begin{array}{c}15 \\
88.2\end{array}$ & 6 & $\begin{array}{c}2 \\
13.3\end{array}$ & $\begin{array}{c}3 \\
20\end{array}$ & $\begin{array}{c}10 \\
66.7\end{array}$ & 4 & $\begin{array}{c}2 \\
13.3\end{array}$ & $\begin{array}{c}4 \\
26.7\end{array}$ & $\begin{array}{c}9 \\
60\end{array}$ & 4 \\
\hline $\begin{array}{l}\text { n. Pronunciation teaching } \\
\text { should help make students } \\
\text { comfortably intelligible to } \\
\text { listeners. }\end{array}$ & 0 & 0 & $\begin{array}{c}18 \\
100\end{array}$ & 5 & 0 & $\begin{array}{c}2 \\
11.8\end{array}$ & $\begin{array}{c}15 \\
88.2\end{array}$ & 5 & $\begin{array}{c}2 \\
13.3\end{array}$ & 0 & $\begin{array}{c}13 \\
86.7\end{array}$ & 4 & 0 & $\begin{array}{c}2 \\
13.3\end{array}$ & $\begin{array}{c}13 \\
86.7\end{array}$ & 5 \\
\hline $\begin{array}{l}\text { o. Teaching pronunciation is } \\
\text { boring. }\end{array}$ & $\begin{array}{c}17 \\
94.4\end{array}$ & 0 & $\begin{array}{c}1 \\
5.6\end{array}$ & 1 & $\begin{array}{c}16 \\
88.9\end{array}$ & $\begin{array}{c}1 \\
5.6\end{array}$ & $\begin{array}{c}1 \\
5.6\end{array}$ & 1 & $\begin{array}{c}10 \\
66.7\end{array}$ & $\begin{array}{c}3 \\
20\end{array}$ & $\begin{array}{c}2 \\
13.3\end{array}$ & 2 & $\begin{array}{c}7 \\
46.7\end{array}$ & $\begin{array}{c}3 \\
20\end{array}$ & $\begin{array}{c}5 \\
33.3\end{array}$ & 3 \\
\hline $\begin{array}{l}\text { p. ESL teachers should avoid } \\
\text { correcting or pointing out } \\
\text { pronunciation errors on the } \\
\text { spot. }\end{array}$ & $\begin{array}{c}7 \\
38.9\end{array}$ & $\begin{array}{c}4 \\
22.2\end{array}$ & $\begin{array}{c}7 \\
38.9\end{array}$ & 3 & $\begin{array}{c}9 \\
50\end{array}$ & $\begin{array}{c}4 \\
22.2\end{array}$ & $\begin{array}{c}5 \\
27.8\end{array}$ & 2.5 & $\begin{array}{c}11 \\
73.3\end{array}$ & 0 & $\begin{array}{c}4 \\
26.7\end{array}$ & 2 & $\begin{array}{c}11 \\
73.3\end{array}$ & $\begin{array}{c}1 \\
6.7\end{array}$ & $\begin{array}{c}3 \\
20\end{array}$ & 2 \\
\hline $\begin{array}{l}\text { q. English sounds (e.g., } \\
\text { the "h" sound in the word } \\
\text { "house") are easier to } \\
\text { teach than global aspects } \\
\text { like stress, rhythm and } \\
\text { intonation. }\end{array}$ & $\begin{array}{c}5 \\
27.8\end{array}$ & $\begin{array}{c}4 \\
22.2\end{array}$ & $\begin{array}{c}9 \\
50\end{array}$ & 3.5 & $\begin{array}{c}5 \\
27.8\end{array}$ & $\begin{array}{c}4 \\
22.2\end{array}$ & $\begin{array}{c}9 \\
50\end{array}$ & 3.5 & $\begin{array}{c}5 \\
33.3\end{array}$ & $\begin{array}{c}3 \\
20\end{array}$ & $\begin{array}{c}7 \\
46.7\end{array}$ & 3 & $\begin{array}{c}4 \\
26.7\end{array}$ & $\begin{array}{c}3 \\
20\end{array}$ & $\begin{array}{c}8 \\
53.3\end{array}$ & 4 \\
\hline $\begin{array}{l}\text { r. Pronunciation instruction } \\
\text { improves the accuracy of } \\
\text { language production rather } \\
\text { than communication on the } \\
\text { whole. }\end{array}$ & $\begin{array}{c}4 \\
22.2\end{array}$ & $\begin{array}{c}3 \\
16.7\end{array}$ & $\begin{array}{c}11 \\
61.1\end{array}$ & 4 & $\begin{array}{c}7 \\
38.9\end{array}$ & $\begin{array}{c}3 \\
16.7\end{array}$ & $\begin{array}{c}8 \\
44.4\end{array}$ & 3 & $\begin{array}{c}2 \\
13.3\end{array}$ & $\begin{array}{c}7 \\
46.7\end{array}$ & $\begin{array}{c}6 \\
40\end{array}$ & 3 & $\begin{array}{c}5 \\
33.3\end{array}$ & $\begin{array}{c}5 \\
33.3\end{array}$ & $\begin{array}{c}5 \\
33.3\end{array}$ & 3 \\
\hline $\begin{array}{l}\text { s. Learners benefit from } \\
\text { paying conscious attention } \\
\text { to the input and becoming } \\
\text { aware of how different } \\
\text { features are produced. }\end{array}$ & 0 & $\begin{array}{c}4 \\
22.2\end{array}$ & $\begin{array}{c}14 \\
77.8\end{array}$ & 4 & $\begin{array}{c}1 \\
5.6\end{array}$ & $\begin{array}{c}2 \\
11.1\end{array}$ & $\begin{array}{c}15 \\
83.3\end{array}$ & 5 & 0 & $\begin{array}{c}4 \\
26.7\end{array}$ & $\begin{array}{c}11 \\
73.3\end{array}$ & 5 & $\begin{array}{c}1 \\
6.7\end{array}$ & $\begin{array}{c}4 \\
26.7\end{array}$ & $\begin{array}{c}10 \\
66.7\end{array}$ & 4 \\
\hline $\begin{array}{l}\text { t. An L2 speaker can have a } \\
\text { strong foreign accent and still } \\
\text { be perfectly understandable. }\end{array}$ & $\begin{array}{c}1 \\
5.9\end{array}$ & $\begin{array}{c}1 \\
5.9\end{array}$ & $\begin{array}{c}15 \\
88.2\end{array}$ & 5 & $\begin{array}{c}3 \\
17.6\end{array}$ & 0 & $\begin{array}{c}14 \\
82.4\end{array}$ & 5 & $\begin{array}{c}1 \\
6.7\end{array}$ & $\begin{array}{c}1 \\
6.7\end{array}$ & $\begin{array}{c}13 \\
86.7\end{array}$ & 5 & $\begin{array}{c}2 \\
13.3\end{array}$ & $\begin{array}{c}1 \\
6.7\end{array}$ & $\begin{array}{l}12 \\
80\end{array}$ & 4 \\
\hline $\begin{array}{l}\text { u. It is difficult to integrate } \\
\text { pronunciation teaching into } \\
\text { regular ESL classes. }\end{array}$ & $\begin{array}{c}6 \\
33.3\end{array}$ & $\begin{array}{c}8 \\
44.4\end{array}$ & $\begin{array}{c}4 \\
22.2\end{array}$ & 3 & $\begin{array}{c}11 \\
61.1\end{array}$ & $\begin{array}{c}2 \\
11.1\end{array}$ & $\begin{array}{c}5 \\
27.8\end{array}$ & 2 & $\begin{array}{c}10 \\
66.7\end{array}$ & $\begin{array}{c}4 \\
26.7\end{array}$ & $\begin{array}{c}1 \\
6.7\end{array}$ & 2 & $\begin{array}{c}7 \\
46.7\end{array}$ & $\begin{array}{c}3 \\
20\end{array}$ & $\begin{array}{c}5 \\
33.3\end{array}$ & 3 \\
\hline $\begin{array}{l}\mathrm{v} \text {. The best person to teach } \\
\text { pronunciation is a native } \\
\text { speaker. }\end{array}$ & $\begin{array}{c}11 \\
61.1\end{array}$ & 0 & $\begin{array}{c}7 \\
38.9\end{array}$ & 2 & $\begin{array}{c}9 \\
50\end{array}$ & $\begin{array}{c}2 \\
11.1\end{array}$ & $\begin{array}{c}7 \\
38.9\end{array}$ & 2.5 & $\begin{array}{c}5 \\
33.3\end{array}$ & $\begin{array}{c}2 \\
13.3\end{array}$ & $\begin{array}{c}8 \\
53.3\end{array}$ & 4 & $\begin{array}{c}5 \\
33.3\end{array}$ & $\begin{array}{c}7 \\
46.7\end{array}$ & $\begin{array}{c}3 \\
20\end{array}$ & 3 \\
\hline
\end{tabular}

Note. $\mathrm{D}=$ Disagree; $\mathrm{U}=$ Unsure or neutral; $\mathrm{A}=$ Agree; $\mathrm{M}=$ Median

Content of unshaded cells $=$ Count and percentage 